\title{
Article \\ Comparative Study on Lead and Copper Biosorption Using Three Bioproducts from Edible Mushrooms Residues
}

\author{
Nathália R. C. M. Castanho ${ }^{1}\left(\mathbb{D}\right.$, Renan A. de Oliveira ${ }^{1}{ }^{\oplus}$, Bruno L. Batista ${ }^{2}$, Bruna M. Freire ${ }^{2}{ }^{\oplus}$, Camila Lange ${ }^{2}$, \\ André M. Lopes ${ }^{3} \mathbb{D}$, Angela F. Jozala ${ }^{1, *} \mathbb{*}$ and Denise Grotto ${ }^{1, *}$ \\ 1 University of Sorocaba, Sorocaba 18023-000, SP, Brazil; nathalia.rcmc@gmail.com (N.R.C.M.C.); \\ renan.oliveira@prof.uniso.br (R.A.d.O.) \\ 2 Center of Natural and Human Sciences, Federal University of ABC, Santo André 09210-170, SP, Brazil; \\ bruno.lemos@ufabc.edu.br (B.L.B.); bruna.freire@ufabc.edu.br (B.M.F.); camilosalange@yahoo.com (C.L.) \\ 3 Faculty of Pharmaceutical Sciences, University of Campinas, Campinas 13083-871, SP, Brazil; \\ amlopes@unicamp.br \\ * Correspondence: angela.jozala@prof.uniso.br (A.F.J.); denise.grotto@prof.uniso.br (D.G.); \\ Tel.: +55-15-2101-7104 (A.F.J. \& D.G.); Fax: +55-15-2101-7000 (A.F.J. \& D.G.)
}

\section{check for}

updates

Citation: Castanho, N.R.C.M.; de Oliveira, R.A.; Batista, B.L.; Freire, B.M.; Lange, C.; Lopes, A.M.; Jozala, A.F.; Grotto, D. Comparative Study on Lead and Copper Biosorption Using Three Bioproducts from Edible Mushrooms Residues. J. Fungi 2021, 7, 441. https://doi.org/10.3390/ jof7060441

Academic Editors: Thomas Edison E. dela Cruz and Fahrul Huyop

Received: 9 April 2021

Accepted: 17 May 2021

Published: 31 May 2021

Publisher's Note: MDPI stays neutral with regard to jurisdictional claims in published maps and institutional affiliations.

Copyright: (c) 2021 by the authors. Licensee MDPI, Basel, Switzerland. This article is an open access article distributed under the terms and conditions of the Creative Commons Attribution (CC BY) license (https:/ / creativecommons.org/licenses/by/ $4.0 /)$.

\begin{abstract}
Agricultural waste products can be used as biosorbents for bioremediation once they are low-cost and high-efficient in pollutants removal. Thus, waste products from mushroom farming such as cutting and substrate of Lentinula edodes (popularly known as shiitake) and Agaricus bisporus (also known as champignon) were evaluated as biosorbents for metallic contaminants copper $(\mathrm{Cu})$ and lead $(\mathrm{Pb})$. Shiitake and champignon stalks, and shiitake substrate (medium in which shiitake was cultivated) were dried, grounded, characterized and experimented to remove $\mathrm{Cu}$ and $\mathrm{Pb}$ from contaminated water. The Sips model was used to establish the adsorption isotherms. Regarding $\mathrm{Cu}$, champignon stalks have the best removal efficiency (43\%), followed by substrate and stalks of shiitake (37 and 30\%, respectively). $\mathrm{Pb}$ removals were similar among three residues (from 72 to $83 \%$ ), with the champignon stalks standing out. The maximum adsorption capacities $\left(q_{\max }\right)$ for $\mathrm{Cu}$ in shiitake and champignon stalks were 22.7 and $31.4 \mathrm{mg} / \mathrm{g}^{-1}$, respectively. For $\mathrm{Pb}, q_{\max }$ for shiitake and champignon stalks, and shiitake substrate were $130.0,87.0$ and $84.0 \mathrm{mg} / \mathrm{g}^{-1}$, respectively. The surface morphology of the champignon stalks revealed an organized and continuous structure. After an interaction with metals, the stalk of champignon accumulated the metal ions into interstices. Mushroom residues showed a relevant adsorption efficiency, especially for $\mathrm{Pb}$. Mushroom farming waste are a very low-cost and promising alternative for removing toxic heavy metals from aquatic environment.
\end{abstract}

Keywords: biosorption; bioremediation; Agaricus bisporus; Lentinula edodes; heavy metals; metal contamination

\section{Introduction}

Contamination by heavy metals arises from the intense and improper disposal of electronic materials and household appliances, automobile industry, coal mining, among other sources [1]. The persistence of metals in the aquatic environment can lead to bioaccumulation, transforming the life cycle of several animals, as they can directly interfere in the enzymatic cellular processes, and morphological differentiation in different organs, such as gills, spleen, liver, and muscles [2,3]. Among metals, lead $(\mathrm{Pb})$ and copper $(\mathrm{Cu})$ compounds are easily found in water, such as rivers, ponds, lakes, tanks, by inappropriate discarding industrial effluents, mainly from steel mills [4].

The public health concern associated with $\mathrm{Pb}$ compound contamination is longstanding, but it is still a serious issue [5]. Contamination with $\mathrm{Pb}$ compound may be linked to the irregular/illegal disposal of waste from factories and mining, especially in undeveloped countries [6]. Some $\mathrm{Pb}$ compounds are highly persistent in the environment as they can be adsorbed by soil and sediments, particularly those rich in hydrous iron oxide. The 
chemical stability occurs as there are several $\mathrm{Pb}$ ligand forms, sometimes linking with another $\mathrm{Pb}$, or some organic or inorganic groups, in addition to the formation of oxides $[7,8]$. Generally, the $\mathrm{Pb}$ concentration in sediments is around 30 to $45 \mathrm{mg} / \mathrm{kg}^{-1}$, but the level can reach 700 to $2600 \mathrm{mg} / \mathrm{kg}^{-1}$ in polluted rivers [9]. Lead compounds inhibit enzymatic activity, such as $\delta$-aminolevulinic acid dehydratase (ALA-D), coproporphyrinogen oxidase, and iron chelatase, causing anemia in human beings [10]. Moreover, $\mathrm{Pb}$ compounds are particularly neurotoxic for children, inducing neurological damage, delayed psychomotor development, and learning difficulties [11], where it reaches a level of $10 \mu \mathrm{g} / \mathrm{dL}^{-1} \mathrm{~Pb}$ in the children's bloodstream [9].

Regarding $\mathrm{Cu}$, this metal is widely used in several segments, from the shape of metal alloys, oil refining, pesticides to micronutrients, involved in numerous enzyme processes [12]. However, in high concentrations, $\mathrm{Cu}$ induces toxic effects $[13,14]$. Copper concentration can vary from region to region, and they are influenced by climatic and geological factors as well as industrial and agricultural activities. Word Health Organization (WHO) guidelines recommend, for drinking water, at most $2 \mathrm{mg} / \mathrm{L}^{-1}$ [15]. In soil, the reference value in Brazil is $35 \mathrm{mg} / \mathrm{kg}^{-1}$, but in industrial regions, the concentrations can reach $10 \mathrm{~g} / \mathrm{kg}^{-1}$ [16]. In a study developed in Europe, vineyards had the highest mean soil $\mathrm{Cu}$ concentration (about $49 \mathrm{mg} / \mathrm{kg}^{-1}$ ) [17]. The toxic effects are diverse, and $10 \mathrm{mg} / \mathrm{day}^{-1}$ of $\mathrm{Cu}$ can cause brain, kidney, and liver damage $[14,15,18]$, in addition to accumulating in tissues such as bone [19].

Coagulation, flocculation, decantation, filtration, and disinfection are conventional methods used by most water treatment plants. However, these conventional methods have some disadvantages, such as the poor ability to remove micromaterials, the use of chemicals and the need for accurate dosing (especially in the flocculation step), frequent monitoring, trained operators, and expense [20]. Bioremediation, for both water and wastewater treatment plants, represents an advantageous alternative due to the reduction in operation steps and chemical uses, the decrease in costs, and moreover by increasing the efficiency in removing contaminants. Bioremediation can be described as a technique in which bacteria, fungi, algae or even a biomolecule or biomaterial are added to a contaminated site to attenuate, decrease, or biochemically degrade the contaminants present there [21]. Bioremediation can take place through biosorption (absorption or adsorption) and biofiltration, among others [22]. Adsorption is one of the main techniques used for decontamination of aqueous medium polluted by metals. A large variety of sorbents can be used to remove heavy metals from the aquatic environment, such as magnetic nanoadsorbents [23] and agricultural residues [24].

Among agricultural residues, those from edible mushroom waste production can be highlighted. Between 1997 and 2012, annual per capita consumption of edible mushrooms increased from about 1 to over $4 \mathrm{~kg} / \mathrm{y}^{-1}$ worldwide [25]. Accordingly, in this way, the generation of their residues increased in the same direction, making stalks and substrates a possible issue, due to their disposal in the environment. Lau et al. [26] declared that $1 \mathrm{~kg}$ of mushrooms can generate $5 \mathrm{~kg}$ of spent mushroom substrate.

Mushroom production wastes can be divided into cuttings and substrate. Cuttings are the stalks of edible mushrooms not suitable for consumption as food, but their cell wall is an important source of chitosan [27]. Chitin and chitosan are compounds able to chelate metals, such as $\mathrm{Pb}$ [28]. The substrate is a lignocellulosic-based material where the mushrooms are cultivated, made of sawdust enriched with vegetable bran. After harvesting, the substrate is discarded into the environment [25].

Despite there being some studies that used edible mushrooms for metal bioremediation, some have applied mushroom biomass [29,30]. Moreover, bacteria and fungi consortium were also studied in removal of metals [31]. Innovatively, in this study we propose: (i) to produce powdered biomaterials only using mushroom residues; (ii) to evaluate these biomaterials from stalks of Agaricus bisporus (champignon) and Lentinula edodes (shiitake), as well as the spent mushroom substrate of shiitake as biosorbents to remove heavy metals such as lead and copper from water. The great innovation of this 
study is the potential use of a low-cost biomaterial, such as mushroom waste production, which is generally discarded. Indeed, these residues can be transformed into a porous biomaterial with high adsorption capacity with a few steps of processing.

\section{Materials and Methods}

In this study, we used two types of residues: the stalks of edible mushrooms not suitable as food, and the spent mushroom substrate (the leftover substrate generated by mushroom industries after harvesting period of mushroom), named here only as substrate.

Menk et al. [32] structurally and chemically characterized the point of zero charges (PZCs) of stalks of shiitake and champignon, and substrate of shiitake. PZC ranges were identified as $4.7 \pm 0.2,6.3 \pm 0.2$, and $4.5 \pm 0.2$ for stalks of shiitake and champignon, and substrate of shiitake, respectively [32]. Thus, all metal solutions were adjusted for the above specific $\mathrm{pH}$ values, since PCZ implies the successful $\mathrm{pH}$ value of the adsorption process. Regarding structural data, analyses were also run in a previous article from our research group [32]. Stalks of shiitake and champignon showed high porosity (71.3 and 70.0 , respectively), compared to $67.2 \%$ porosity to substrate of shiitake. Additionally, regarding chemical characterization, the vibrational spectrum of both stalks and substrate were comparable to the chitosan spectrum [32].

\subsection{Sample Preparation}

The stalks and the substrate of shiitake were supplied by local producers from Sorocaba (São Paulo State, Brazil). The stalks of champignon were supplied by producers from Bragança Paulista (São Paulo State, Brazil). The substrate included a mixture of eucalyptus sawdust used for mushroom cultivation, containing rice and wheat bran, charcoal, and calcium carbonate (for $\mathrm{pH}$ correction). The mushrooms remained on this substrate for 4 to 7 months until they were ready for harvest. The stalks and substrate were ovendried (at $50{ }^{\circ} \mathrm{C}$ for two days). Subsequently, the dried material was ground in a knife mill (Marconi ${ }^{\circledR}$-MA340, \#0004201) and passed through a sieve of different particle sizes. The particles size of $<0.180 \mathrm{~mm}$ ( $>80$ mesh) used in this study was chosen based on our previous study [32].

\subsection{Removal Efficiency Over Time}

The metals $\mathrm{Pb}$ (Lead (II) acetate trihydrate (99.999\%, trace metals basis) and $\mathrm{Cu}$ (Copper (II) sulfate pentahydrate $(\geq 98.0 \%)$ were purchased from Sigma-Aldrich (St. Louis, $\mathrm{MO}$, USA). The assays were run according to Menk et al. [32]. For $\mathrm{Cu}, 0.5 \mathrm{~g}$ of the stalks of shiitake, champignon, or shitake substrate was added to an Erlenmeyer flask containing $60 \mathrm{~mL}$ of $\mathrm{Cu}$ solution of $1000 \mathrm{mg} / \mathrm{L}^{-1}$. Pb tests were run in the same conditions described above $\left(\mathrm{Pb}\right.$ solution of $\left.1000 \mathrm{mg} / \mathrm{L}^{-1}\right)$. The metal solutions were made with bidistilled water. The concentrations are higher than those found environmentally, and these concentrations were chosen based on studies of Chen et al. and Amar et al. [33,34]. However, removal efficiency and isotherms need to be run in high concentrations in order to saturate the aqueous medium and thus be able to evaluate the bioremediation potential. The metal solutions were adjusted for specific $\mathrm{pH}$ values according to $\mathrm{PZC}$, using $\mathrm{NaOH}$ or $\mathrm{HCl}$ solution.

Each metal was placed independently in an Erlenmeyer flask. The flasks were kept under constant agitation at $100 \mathrm{rpm}$ in an orbital shaker (Nova Técnica, NT 715), orbital with $10 \mathrm{~mm}$ amplitude, for specified times of 10,20,30,45, 60, 120, 240,360, 720, and $1440 \mathrm{~min}$ at $25^{\circ} \mathrm{C}$. The temperature of $25^{\circ} \mathrm{C}$ was chosen as it is considered the standard ambient temperature, at which any water treatment plant could act. At each period, samples from metal solutions were taken, and the adsorbents were removed completely from the solution, using a $1.22 \mu \mathrm{m}$ particle retention filter. The number of samples, in total, was 20 per metal. The remaining solutions were analyzed using inductively coupled plasma mass spectrometer (ICP-MS) according to Section 2.4. 
The removal efficiency of the heavy metal, here indicated as metal removal (\%wt), from an aqueous solution, was calculated by Equation (1):

$$
\text { Metal removal }(\%)=\frac{\left(C_{0}-C_{e}\right)}{C_{0}} \times 100
$$

where $C_{0}$ is the initial concentration of the metal solution $\left(\mathrm{mg} / \mathrm{L}^{-1}\right)$ and $C e$ is the equilibrium concentration $\left(\mathrm{mg} / \mathrm{L}^{-1}\right)$, which means the final concentration of the metal in the solution at a specific time.

\subsection{Adsorption Isotherm}

The capacity of the adsorbent to retain the contaminant on its surface was assessed through assays with different concentrations of the contaminant, related to the removal efficiency over time. For this, $0.5 \mathrm{~g}$ of each adsorbent was added to $60 \mathrm{~mL}$ of different concentrations $\left(10,25,100,250,500,750\right.$, and $\left.1000 \mathrm{mg} / \mathrm{L}^{-1}\right)$ of each metal. The systems were kept under constant agitation at $100 \mathrm{rpm}$, at $25^{\circ} \mathrm{C}$, in an orbital shaker (Nova Técnica, NT 715) for $24 \mathrm{~h}$. The systems were filtered according to Section 2.2 and analyzed using ICP-MS according to Section 2.4.

The adsorption equilibrium measures the concentration of a solute in an equilibrium state that can be absorbed by a tested absorbent. Therefore, the adsorption equilibrium $(q)$ can be calculated as the equilibrium concentration of a solute $\left(C_{e}\right)$ subtracted from the initial concentration of the solute $\left(C_{0}\right)$ in $\mathrm{mg} / \mathrm{L}^{-1}$ for a given mass of adsorbent $(\mathrm{m})$ added in a volume $(V)$. It is expressed in $\mathrm{mg} \mathrm{g}^{-1}$ and is calculated by Equation (2):

$$
q=\frac{\left(C_{0}-C_{e}\right) \cdot V}{m}
$$

The adsorption isotherm was estimated according to the Sips model, which combines the Langmuir and Freundlich models [35,36], and can be expressed by Equation (3):

$$
q=\frac{q_{\max } \cdot K_{L F} \cdot C_{e}{ }^{n}}{\left(1+K_{L F} \cdot C_{e}{ }^{n}\right)}
$$

where $q$ is the amount adsorbed, $q_{\max }$ is the maximum adsorption capacity, $K_{L F}$ is the equilibrium constant, $\mathrm{C} e$ is the equilibrium concentration, and $n$ is the heterogeneity parameter.

The $K_{L F}, q_{\max }$ and $n$ parameters were estimated by OriginPro ${ }^{\circledR} 8$ software (OriginLab Corporation, Northampton, MA, USA).

\subsection{Evaluation of Copper $(\mathrm{Cu})$ and Lead $(\mathrm{Pb})$ in Water}

$\mathrm{Cu}$ and $\mathrm{Pb}$ concentrations in the solution were measured using an inductively coupled plasma mass spectrometer (ICP-MS) with collision cell. The equipment was operated with high-purity argon (99.999\%, Praxair, São Paulo State, Brazil). The operating conditions were set according to [37]. The samples were acidified $\left(1 \% v / v^{-1}\right)$ with sub-boiled (DST-1000, Savillex, Eden Prairie, MN, USA) $14 \mathrm{M} \mathrm{HNO}_{3}$ (Synth, Brazil) and directly injected into the ICP-MS equipment.

Standards for calibration were prepared by diluting the commercial standards $\left(10,000 \mathrm{ng} / \mathrm{mL}^{-1}\right.$ acquired from Perkin Elmer, Waltham, MA, USA) in $\mathrm{HNO}_{3} 1 \% v / v^{-1}$ over the range of 0 to $100 \mathrm{ng} / \mathrm{mL}^{-1}$. The correlation coefficient $\left(\mathrm{R}^{2}\right)$ for calibration curves was $>0.9999$. The performance of the method was controlled by the analysis of blanks (ultrapure water) and Standard Reference Material (SRM) 1640a Natural Water, from the National Institute of Standard and Technology.

\subsection{Biomaterial Morphology}

The mushroom surface morphology and elemental compositions in the biosorbent surfaces were, respectively, investigated using Scanning Electron Microscopy (SEM) and Energy Dispersive Spectroscopy (EDS) (JEOL, Model IT200). 
This assay was carried out with the adsorbent that showed the best set of results-in this case, the champignon. Three samples were evaluated: (i) stalks of champignon (considered blank sample, without any contact with metal solutions); (ii) stalks of champignon after $20 \mathrm{~min}$ in contact with Cu solution; and (iii) stalks of champignon after $120 \mathrm{~min}$ in contact with $\mathrm{Pb}$ solution. The samples that had contact with the metal solution were ovendried at $50{ }^{\circ} \mathrm{C}$, for one day before being morphologically evaluated. Sample preparation for both SEM and EDS consisted of placing them on carbon tape for metallization with gold ( $99.9 \%$ pure).

\section{Results and Discussion}

\subsection{Removal Efficiency over Time}

This study evaluated the stalks of champignon and shiitake mushrooms and the shiitake substrate as biosorbents for $\mathrm{Pb}$ and $\mathrm{Cu}$. The $\mathrm{Cu}$ removal efficiency over time is shown in Figure 1A.
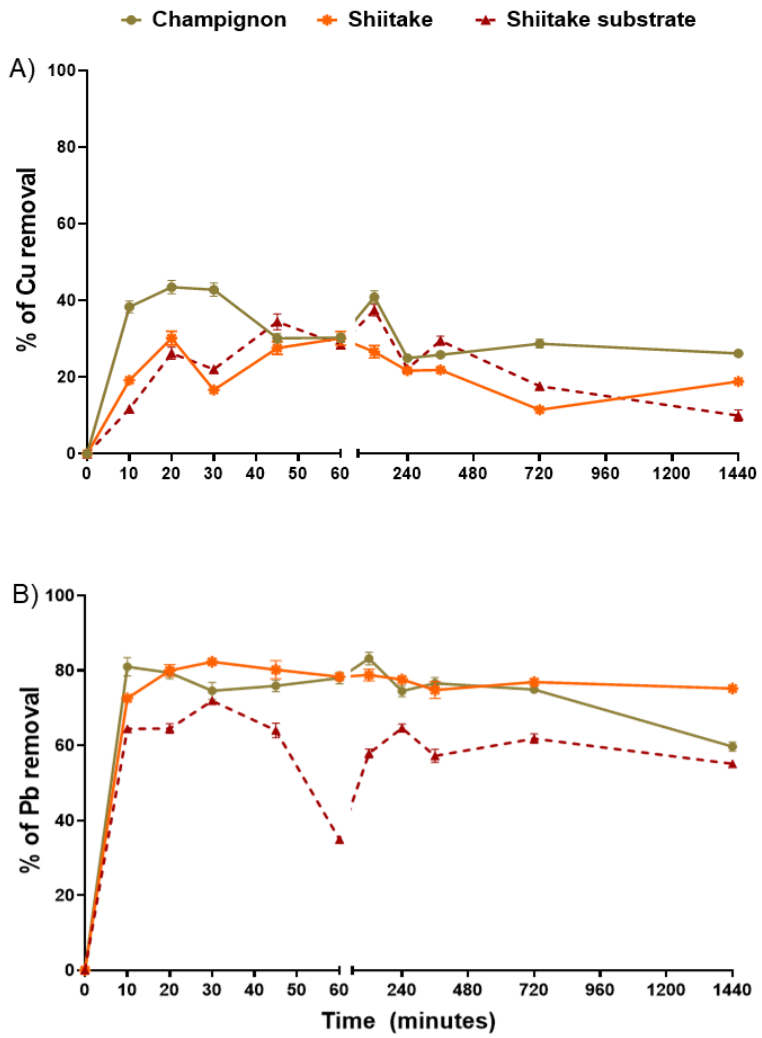

Figure 1. Copper $(\mathrm{Cu})(\mathrm{A})$ and Lead $(\mathrm{Pb})(\mathbf{B})$ removals. Both were assessed with $\mathrm{Cu}$ or $\mathrm{Pb}$ solution, $1000 \mathrm{mg} / \mathrm{L}^{-1}$, and $0.5 \mathrm{~g}$ of adsorbent, such as stalks of shiitake and champignon, and substrate of shitake.

The highest rates of $\mathrm{Cu}$ removal for shiitake substrate were 34 and $37 \%$ at 45 and $120 \mathrm{~min}$, respectively, followed by desorption. Maximum removal rates for stalks of shiitake were $30 \%$ at 20 and $60 \mathrm{~min}$. For stalks of champignon, $\mathrm{Cu}$ removal reached $43 \%$ in the first $20 \mathrm{~min}$. Stability was achieved after approximately $720 \mathrm{~min}$. However, for greater certainty of the stabilization of the adsorption/desorption rate of the samples, a time of $24 \mathrm{~h}$ was adopted for the $\mathrm{Cu}$ isotherm assays.

The results of $\mathrm{Pb}$ removal efficiency over time are shown in Figure 1B. The biosorbents showed very satisfactory results, with adsorption rates above $60 \%$. Maximum removal rates varied from $72 \%$ for the substrate of shiitake (30 $\mathrm{min}), 82 \%$ for stalks of shiitake (30 $\mathrm{min}$ ), and $83 \%$ for stalks of champignon $(120 \mathrm{~min}$ ). The stability was reached after about $360 \mathrm{~min}$. Therefore, $\mathrm{Pb}$ isotherm assays were evaluated for $24 \mathrm{~h}$. Pb removal efficiency 
was much more effective in stalks than in substrate. Results from our previous research, regarding microtomography, can explain these results, since shiitake and champignon stalks had better open pore and porosity \% in comparison to the substrate [32].

Liu et al. evaluated the capacity of Pleurotus cornucopiae mushroom in removing two different metals (i.e., $\mathrm{Cu}$ and $\mathrm{Cadmium}-\mathrm{Cd}$ ) from substrates naturally contaminated with those metals. Substrates were evaluated after the growth of the mushrooms, and the results showed that $P$. cornucopiae was able to reach 36 and $22 \%$ of $\mathrm{Cu}$ and $\mathrm{Cd}$ retention, respectively [38]. Data for $\mathrm{Cu}$ removal were similar to the results found for the adsorbents evaluated by our group.

Comparing mushroom residues with other adsorbents, El-Ashtoukhy et al. evaluated the removal of $\mathrm{Cu}$ and $\mathrm{Pb}$ by pomegranate peel, reaching adsorbent saturation after $120 \mathrm{~min}$ [39]. These authors found the adsorption of $\mathrm{Pb}$ in raw pomegranate peel reached $90 \%$, similar to those obtained with the stalk of champignon, while for $\mathrm{Cu}$ they found $98 \%$ removal. In another interesting study, it was observed that the removal capacity by Penicillium simplicissimum after $15 \mathrm{~min}$ is constant for $\mathrm{Pb}$, reaching an adsorption of $56.6 \%$ [33]. Amar et al. evaluated the adsorption of metals $(\mathrm{Pb}$ and $\mathrm{Cu}$ ) for olive stones, and the maximum removal rate was $1 \mathrm{~h}$, with 75.2 and $40 \%$, respectively [34]. In another study, Amarasinghe and Williams used tea waste as a sorbent and they achieved adsorption rates of 94 and $70 \%$ for $\mathrm{Pb}$ and $\mathrm{Cu}$, respectively [40].

On the other hand, comparing the metal removal efficiency, it is important to realize a common point in all the studies reported, regardless of the type of biosorbent: the $\mathrm{Cu}$ biosorption is always less than other metals. In this way, we could suggest that the biosorbents, including the mushroom residues, are more easily saturated with this metal (i.e., $\mathrm{Cu}$ ). Thus, it may be necessary to use a larger mass of biosorbent for this type of contaminant.

\subsection{Adsorption Isotherm}

Sips theoretical isothermal model was applied to the three adsorbents, and results for $\mathrm{Cu}$ and $\mathrm{Pb}$ are depicted in Figure 2A,B, respectively.

The summary comparison between $\mathrm{Pb}$ and $\mathrm{Cu}$ isotherms is presented in Table 1 . The Sips model did not fit adequately for $\mathrm{Cu}$ in the stalk of shitake, since the $\mathrm{R}^{2}$ value was very low (0.546). The Sips model is the union of Langmuir and Freundlich models, and these models were evaluated individually, but they did not fit adequately (data not showed). We suppose that the concentrations of $\mathrm{Cu}$ solution used were not suitable, and it could be a limitation of the method. On the other hand, for the $\mathrm{Pb}$, the Sips model presented an excellent fit to all adsorbents (i.e., with $\mathrm{R}^{2}$ values $>0.919$ ).
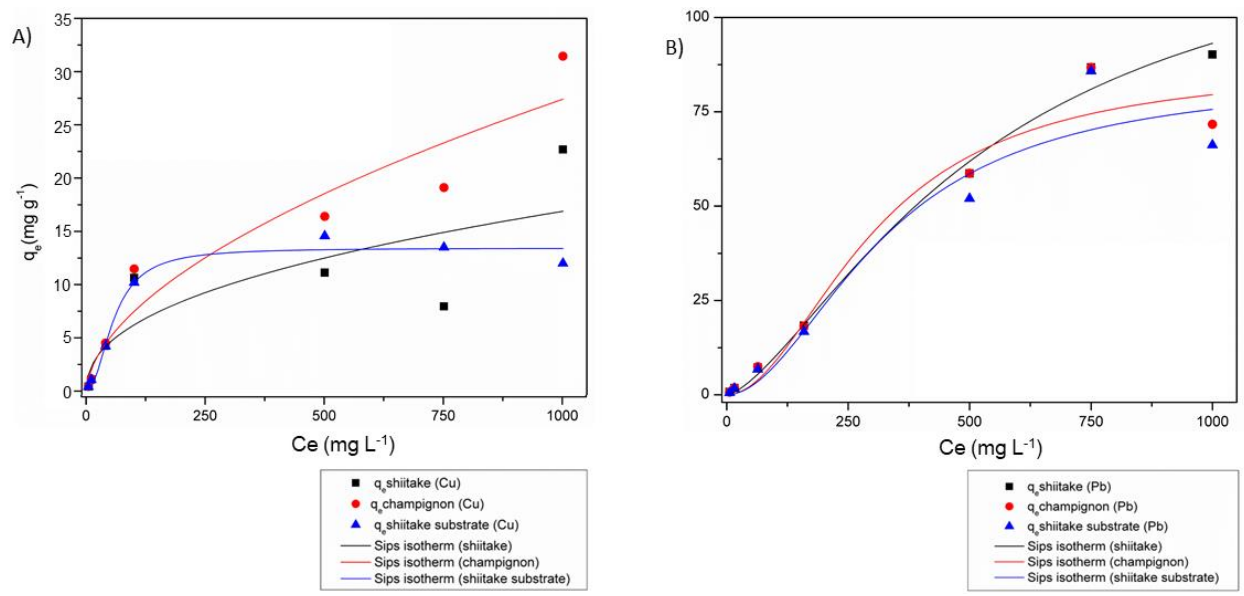

Figure 2. Sips theoretical isotherms to Copper $(\mathrm{Cu})(\mathrm{A})$ and Lead $(\mathrm{Pb})(\mathrm{B})$ by stalks of shiitake, stalks of champignon, and substrate of shitake. $C_{e}$ and $q_{e}$ correspond to the equilibrium concentration $\left(\mathrm{mg} / \mathrm{L}^{-1}\right)$ and the amount adsorbed in equilibrium $\left(\mathrm{mg} / \mathrm{g}^{-1}\right)$, respectively. 
Table 1. A general summary of the isotherm model parameters according to the Sips model and comparing the tree biosorbents evaluated. The $K$ and $q_{\max }$ parameters correspond to the equilibrium constant and maximum adsorption capacity, respectively. The heterogeneity is represented by $n$.

\begin{tabular}{|c|c|c|c|}
\hline Parameters & Stalk of Champignon & Stalk of Shiitake & Substrate of Shiitake \\
\hline & \multicolumn{3}{|c|}{ Copper $(\mathrm{Cu})$} \\
\hline$R^{2}$ & 0.889 & 0.546 & 0.970 \\
\hline$K\left(\mathrm{~L} / \mathrm{mg}^{-1}\right)$ & $3.21 \times 10^{-5}$ & $8.82 \times 10^{-5}$ & $2.6 \times 10^{-4}$ \\
\hline$q_{\max }\left(\mathrm{mg} / \mathrm{g}^{-1}\right)$ & 31.44 & 22.68 & 14.57 \\
\hline \multirow[t]{2}{*}{$n$} & 0.56 & 0.43 & 2.04 \\
\hline & \multicolumn{3}{|c|}{ Lead $(\mathrm{Pb})$} \\
\hline $\mathrm{R}^{2}$ & 0.953 & 0.991 & 0.919 \\
\hline$K\left(\mathrm{~L} / \mathrm{mg}^{-1}\right)$ & $1.40 \times 10^{-5}$ & $9.56 \times 10^{-5}$ & $1.48 \times 10^{-5}$ \\
\hline$q_{\max }\left(\mathrm{mg} / \mathrm{g}^{-1}\right)$ & 86.74 & 90.18 & 8.79 \\
\hline$n$ & 1.95 & 1.47 & 1.92 \\
\hline
\end{tabular}

The highest adsorption capacity $\left(q_{\max }\right)$ for $\mathrm{Cu}$ occurred at $1000 \mathrm{mg} \mathrm{L}^{-1}$ for stalks of champignon $\left(31.44 \mathrm{mg} \mathrm{g}^{-1}\right)$ followed by stalks of shiitake $\left(22.68 \mathrm{mg} / \mathrm{g}^{-1}\right)$. On the other hand, for the substrate of shiitake, the highest $q_{\max }\left(14.57 \mathrm{mg} / \mathrm{g}^{-1}\right)$ was obtained at $500 \mathrm{mg} / \mathrm{L}^{-1}$.

The equilibrium constants $(K)$ for $\mathrm{Cu}$ are also presented in Table 1 . These results express the ratio between the adsorption and desorption constants over time. Li et al. evaluated the removal of $\mathrm{Cu}$, Zinc, and Mercury from water by inedible stipe of mushrooms [41]. They used different mushroom species from ours and demonstrated that Auricularia polytricha had $K$ values of 0.2893 and 0.0510 by the Freundlich and Langmuir models, respectively. $K$ is a factor influenced by several aspects, such as source of biomaterial (i.e., type of species), physiological age, and tissue morphology [42]. Thus, once we used different species, a variation in $K$ values can occur.

The empirical parameter of system heterogeneity $(n)$ determines that the Sips equation will be reduced to a Langmuir equation if $n \geq 1$, or the Freundlich equation if $n \leq 1[36,43,44]$. Thus, for $\mathrm{Cu}$, shitake and champignon stalks indicated a better affinity to the Freundlich equation, whereas for shiitake substrate the $n$ value indicated a better fit with the Langmuir isotherm.

The best $\mathrm{Pb} q_{\max }$ occurred for the initial concentration of $1000 \mathrm{mg} / \mathrm{L}^{-1}$ for the stalk of shitake $\left(90.18 \mathrm{mg} / \mathrm{g}^{-1}\right)$, while for the stalk of champignon and substrate of shiitake (both with a concentration of $750 \mathrm{mg} / \mathrm{L}^{-1}$ ), the best experimental values were 86.74 and $8.79 \mathrm{mg} / \mathrm{g}^{-1}$, respectively. Comparatively, the $q_{\max }$ obtained by the Sips equation was similar to the experimental values of $130.0 \mathrm{mg} / \mathrm{g}^{-1}$ for shiitake stalks, $87.0 \mathrm{mg} / \mathrm{g}^{-1}$ for champignon stalks, and $84.0 \mathrm{mg} / \mathrm{g}^{-1}$ for shiitake substrate. The $n$ values for $\mathrm{Pb}$ indicated a better experimental affinity to the Langmuir equation (i.e., $n \geq 1$ ).

In study about soil bioremediation, champignon was studied as an adsorbent for $\mathrm{Pb}$ and $\mathrm{Cd}$ [45]. The authors achieved isotherm results akin to the present study; however, for $\mathrm{Pb}$, the $\mathrm{R}^{2}$ obtained for the Langmuir model was 0.960 and the $q_{\max }$ was $19.7 \mathrm{mg} / \mathrm{g}^{-1}$. Similar data were found in a study using four samples: raw pomegranate peel, activated carbon prepared from pomegranate peel (AC1), activated carbon prepared from chemically treated (phosphoric acid and zinc chloride 1:1 solution) pomegranate peel (AC2) and finally activated carbon prepared from chemically treated (n nitric acid 10\%wt solution) pomegranate peel (AC3). The best $R^{2}$ for Pb, explained by the hydration enthalpy, was $R^{2}$ of 0.9994 in the raw sample, followed by AC1 (0.9989), AC2 (0.9978), and AC3 (0.9994), indicating the occurrence of a higher activity of $\mathrm{Pb}$ cations than $\mathrm{Cu}$ cations for adsorbents [39]. In our case, the obtained $\mathrm{R}^{2}$ values, according to the Sips model for $\mathrm{Pb}$, were 0.953 for stalks of champignon, 0.991 for stalk of shiitake, and 0.919 for substrate of shiitake. 


\subsection{Scanning Electron Microscope (SEM)}

By using SEM, the adsorbent with the best result set for adsorptive capacity was evaluated. The stalk of champignon was chosen as the best adsorbent, considering both the removal efficiency and the isotherm. Thus, the powder from stalks of champignon was evaluated before contact with the metal solutions (considered blank sample, Figure 3A), and after 20 and $120 \mathrm{~min}$ in contact with $\mathrm{Cu}$ and $\mathrm{Pb}$, respectively, Figure 3B,C.
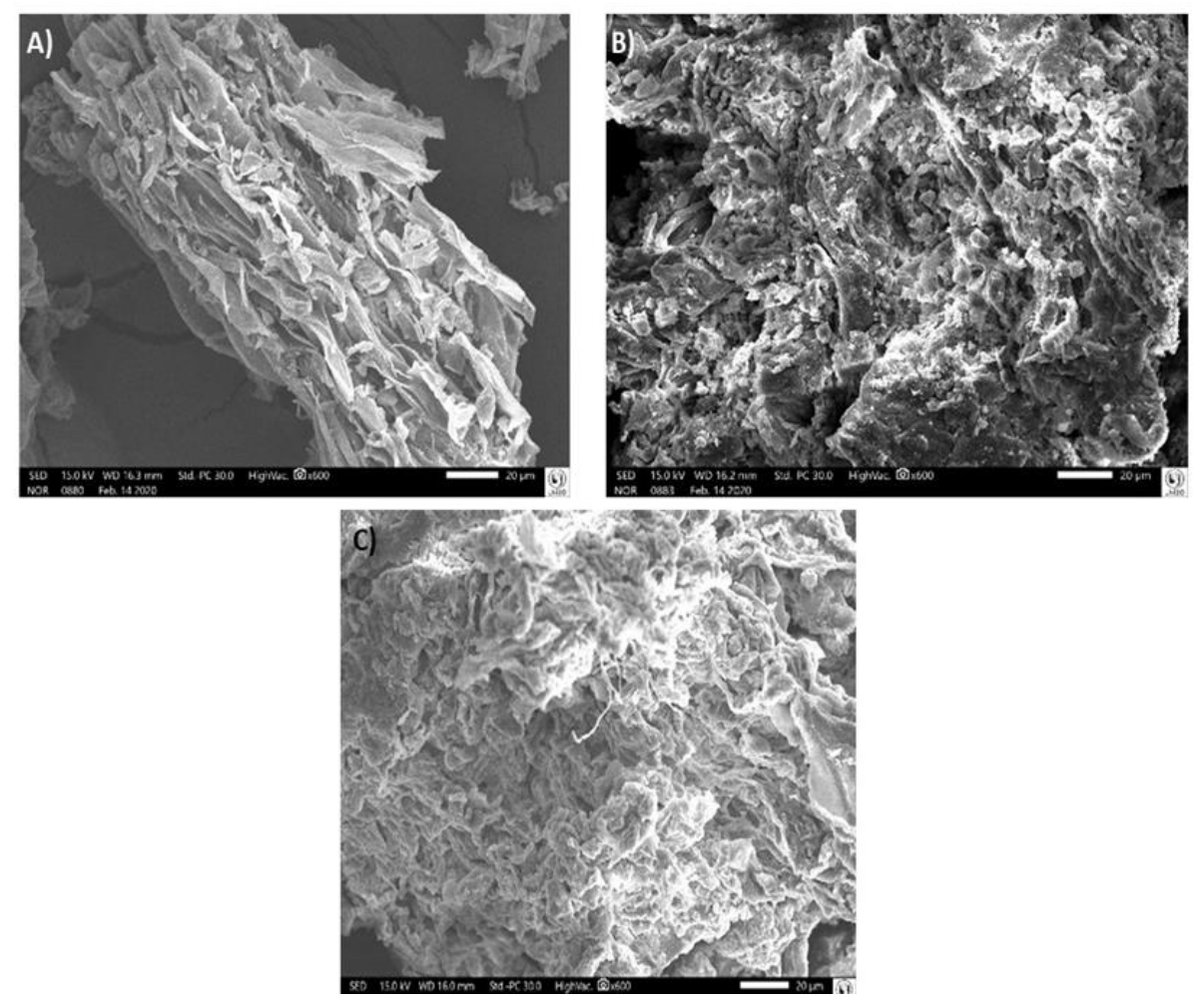

Figure 3. Scanning electron microscopy (SEM) of particles from stalks of champignon (A); stalks of champignon after 20 min of contact with $\mathrm{Cu}(\mathrm{B})$; and stalks of champignon after $120 \mathrm{~min}$ in contact with $\mathrm{Pb}(\mathrm{C})$. Magnification of $600 \times$.

Figure 3A shows that the stalks of champignon particles, without metal interaction (only oven-dried at $50{ }^{\circ} \mathrm{C}$, grounded and sieved), presented natural and continuous structures, with smoother and more organized aspects. This structure could provide a large surface area and facilitate mass retention, contributing to the adsorption process. The images corresponding to the particles of the champignon stalks in contact with the metals (Figure 3B,C) presented an accumulation of these metallic ions, resembling more coiled structures with residues in their interstices. Qiao et al. reported structural changes in the L. edodes mushroom surface after adsorption of Cd. According to these authors, chemical interactions between functional groups such as hydroxyl groups would be responsible for the marked changes [46]. We also suggested that the metals $(\mathrm{Cu}$ and $\mathrm{Pb})$ could change the functional groups from multimer to monomers, increasing the number of exposed functional groups and consequently the absorbent area. Moreover, it is important to consider the metal solutions in our study, which had their $\mathrm{pH}$ values adjusted according to PCZ. We propose the adjustment implies the success of the adsorption process by arranging the structure of particles, facilitating the interactions between metals and adsorbent.

The elementary chemical analysis carried out by EDS showed that the champignon stalks did not present any mass percentage of $\mathrm{Cu}$ and $\mathrm{Pb}$ (Figure $4 \mathrm{~A}$ ) before contact. On the other hand, the mass percentages of $\mathrm{Cu}$ and $\mathrm{Pb}$ found in the particles after contact with the elements were $2.51 \pm 0.06$ and $14.98 \pm 0.09 \mathrm{wt} \%$ (Figure $4 \mathrm{~B}, \mathrm{C}$, respectively). These findings corroborate the removal efficiency and isotherm data. For example, the presence of chitosan 
was evidenced as a component of the champignon, considering the characterization of chemical groups performed by Menk et al. in the champignon stalk [32]. In this sense, hydroxyl, carboxyl, and amide groups indicated that polysaccharides, as well as proteins present on mushrooms [46], can bind metals through chemical interactions, facilitating the adsorption process.

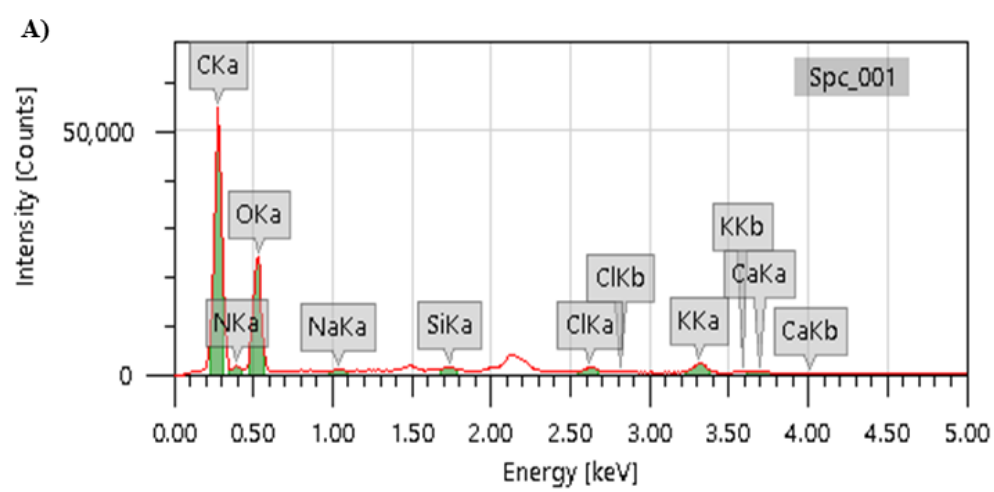

B)

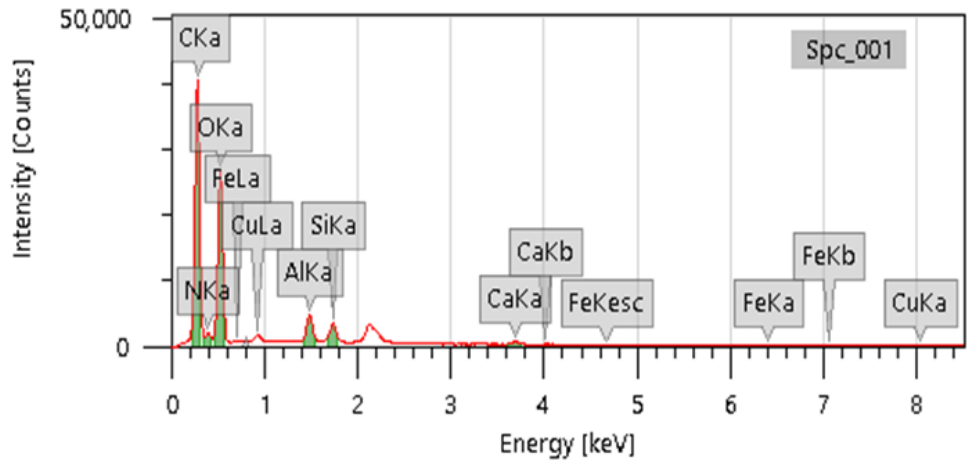

C)

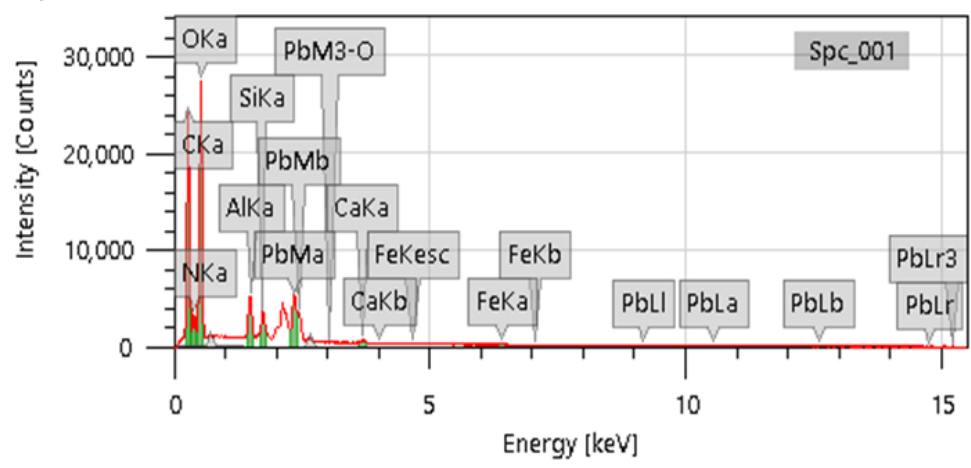

Figure 4. Energy dispersive spectroscopy (EDS) spectrums separated into peaks of the capital letters $\mathrm{K}, \mathrm{L}$ or $\mathrm{M}$ indicate the shell containing the chemical element, whereas the greek letters $(\mathrm{a}=\mathrm{alfa}$, $\mathrm{b}=$ beta, $\mathrm{r}=\mathrm{ro}, \mathrm{M}=\mathrm{mi}$ ) indicate energy in Kev; in ground champignon (A), champignon after $20 \mathrm{~min}$ of contact with $\mathrm{Cu}(\mathbf{B})$, and after $120 \mathrm{~min}$ in contact with $\mathrm{Pb}(\mathbf{C})$.

\section{Conclusions}

Mushroom residues are promising biomaterials with favorable properties for adsorption of a wide range of environmental contaminants. In this study, stalks and substrates from two types of mushrooms showed to be an appropriate matrix for metal adsorption for contaminated water. For $\mathrm{Pb}$, the Sips model proved to be satisfactory, with a very good adsorption capacity for the three biosorbents. This work also demonstrated that stalk of champignon was the best candidate for the adsorption process, considering both the removal efficiency and the isotherm model. The biomaterials proposed in this work are versatile, non-toxic, and they can represent an ecofriendly alternative for biosorbents, once 
they are easily accessible and there is no need for any synthetic route for its manufacture. More specifically, we could suggest the powder of the stalk of champignon has the potential to be used directly in water treatment plants, with subsequent removal by a simple filtration process, or even as packing fixed-bed columns.

Author Contributions: N.R.C.M.C., conceptualization, investigation, methodology and writingoriginal draft; R.A.d.O., methodology and data analysis; B.L.B., methodology and data analysis; B.M.F., methodology and data analysis; C.L., methodology and data analysis; A.M.L., data analysis and writing — review and English editing; A.F.J., conceptualization and writing-review; D.G., project administration, funding acquisition, and writing - review and editing. All authors have read and agreed to the published version of the manuscript.

Funding: The financial support from the State of São Paulo Research Foundation (FAPESP/Brazil, processes \#2016/22873-4, \#2017/10789-1, and \#2018/10799-0).

Institutional Review Board Statement: Not applicable.

Informed Consent Statement: Not applicable.

Data Availability Statement: Data and publication materials are available from the corresponding author upon reasonable request.

Conflicts of Interest: The authors declare no conflict of interest.

\section{References}

1. Kang, C.-H.; Oh, S.J.; Shin, Y.; Han, S.-H.; Nam, I.-H.; So, J.-S. Bioremediation of lead by ureolytic bacteria isolated from soil at abandoned metal mines in South Korea. Ecol. Eng. 2015, 74, 402-407. [CrossRef]

2. Islam, M.S.; Ahmed, M.K.; Raknuzzaman, M.; Habibulla-Al-Mamun, M.; Islam, M.K. Heavy metal pollution in surface water and sediment: A preliminary assessment of an urban river in a developing country. Ecol. Indic. 2015, 48, 282-291. [CrossRef]

3. Abalaka, S.E.; Enem, S.I.; Idoko, I.S.; Sani, N.A.; Tenuche, O.Z.; Ejeh, S.A.; Sambo, W.K. Heavy Metals bioaccumulation and health risks with associated histopathological changes in Clarias gariepinus from the Kado Fish Market, Abuja, Nigeria. J. Health Pollut. 2020, 10, 200602. [CrossRef]

4. Wang, X.; Li, X.; Liu, G.; He, Y.; Chen, C.; Liu, X.; Li, G.; Gu, Y.; Zhao, Y. Mixed heavy metals removal from wastewater by discarded mushroom-stick biochar: Adsorption properties and mechanisms. Environ. Sci. Process. Impacts 2019, 21, 584-592. [CrossRef]

5. Obeng-Gyasi, E. Sources of lead exposure in various countries. Rev. Environ. Health 2019, 34, 25-34. [CrossRef]

6. Rees, N.; Fuller, R. The Toxic Truth: Children's Exposure to Lead Pollution Undermines a Generation of Future Potential, 2nd ed.; Unicef and Pure Earth: New York, NY, USA, 2020. Available online: https://www.unicef.org/media/73246/file/The-toxic-truthchildren $\%$ E2\%80\%99s-exposure-to-lead-pollution-2020.pdf (accessed on 15 January 2021).

7. Meena, R.A.A.; Sathishkumar, P.; Ameen, F.; Yusoff, A.R.M.; Gu, F.L. Heavy metal pollution in immobile and mobile components of lentic ecosystems-a review. Environ. Sci. Pollut. Res. Int. 2017, 25, 4134-4148. [CrossRef]

8. Chaney, R.L.; Mielke, H.W.; Sterrett, S.B. Speciation, mobility, and bioavailability of soil lead. Proc. Intern. Conf. Lead in Soils: Issues and Guidelines. B.E. Davies \& B.G. Wixson (eds.). Environ. Geochem. Health 1989, 11, 105-129.

9. European Food Safety Authority. Scientific opinion on lead in food. EFSA J. 2010, 8, 1570. [CrossRef]

10. Do Nascimento, S.N.; Barth, A.; Göethel, G.; Baierle, M.; Charão, M.F.; Brucker, N.; Moro, A.M.; Bubols, G.B.; Sobreira, J.S.; Sauer, E.; et al. Cognitive deficits and ALA-D-inhibition in children exposed to multiple metals. Environ. Res. 2015, 136, 387-395. [CrossRef]

11. Dórea, J.G. Environmental exposure to low-level lead $(\mathrm{Pb})$ co-occurring with other neurotoxicants in early life and neurodevelopment of children. Environ. Res. 2019, 177, 1-13. [CrossRef]

12. Taylor, A.A.; Tsuji, J.S.; Garry, M.R.; McArdle, M.E.; Goodfellow, W.L.; Adams, W.J.; Menzie, C.A. Critical review of exposure and effects: Implications for setting regulatory health criteria for ingested copper. Environ. Manag. 2019, 65, 131-159. [CrossRef]

13. U.S. EPA. Regional Screening Levels (RSLs)_Generic Tables November 2020; U.S. EPA: Washington, DC, USA. Available online: https:/ / www.epa.gov/risk/regional-screening-levels-rsls-generic-tables (accessed on 8 May 2021).

14. Kalita, J.; Kumar, V.; Misra, U.K.; Bora, H.K. Memory and learning dysfunction following copper toxicity: Biochemical and immunohistochemical basis. Mol. Neurobiol 2017, 55, 3800-3811. [CrossRef]

15. Agency for Toxic Substances and Disease Registry (ATSDR). Interaction Profile for Arsenic, Cadmium, Chromium and Lead; U.S. Department of Health and Human Services, Public Health Service: Atlanta, GA, USA, 2004. Available online: https:/ /www.atsdr. cdc.gov/interactionprofiles/ip-metals2/ip06.pdf (accessed on 4 May 2021).

16. Companhia Ambiental do Estado de São Paulo (CETESB). Cobre. FiT-Ficha de Informação Toxicológica. 2020. Available online: https:/ / cetesb.sp.gov.br/laboratorios/wp-content/uploads/sites/24/2013/11/Cobre.pdf (accessed on 4 May 2021). 
17. Ballabio, C.; Panagos, P.; Lugato, E.; Huang, J.-H.; Orgiazzi., A.; Jones, A.; Fernández-Ugalde, O.; Borrelli, P.; Montanarella, L. Copper distribution in European topsoils: An assessment based on LUCAS soil survey. Sci. Total Environ. 2018, 636, 282-298. [CrossRef]

18. Squitti, R.; Ghidoni, R.; Simonelli, I.; Ivanova, I.D.; Colabufo, N.A.; Zuin, M.; Benussi, L.; Binetti, G.; Cassetta, E.; Rongioletti, M.; et al. Copper dyshomeostasis in Wilson disease and Alzheimer's disease as shown by serum and urine copper indicators. J. Trance Elem. Med. Bio. 2018, 45, 181-188. [CrossRef]

19. Kimmel, C.A.; Garry, M.R.; DeSesso, J.M. Relationship between bent long bones, bent scapulae, and wavy ribs: Malformations or variations? Birth Defects Res. B Dev. Reprod. Toxicol. 2014, 101, 379-392. [CrossRef]

20. World Health Organization. Water Treatment. Who Seminar Pack for Drinking-Water Quality. 2007. Available online: http: / /www.who.int/water_sanitation_health/dwq/S12.pdf (accessed on 28 April 2021).

21. Bernoth, L.; Firth, I.; Mcallister, P.; Rhodes, S. Biotechnologies for remediation and pollution control in the mining industry. Miner. Metall. Proc. 2000, 17, 105-111. [CrossRef]

22. Corral-Bobadilla, M.; González-Marcos, A.; Vergara-González, E.; Alba-Elías, F. Bioremediation of wastewater to remove heavy metals using the spent mushroom substrate of Agaricus bisporus. Water 2019, 11, 454. [CrossRef]

23. Khan, F.S.A.; Mubarak, N.M.; Khalid, M.; Walvekar, R.; Abdullah, E.C.; Mazari, S.A.; Nizamuddin, S.; Karri, R.R. Magnetic nanoadsorbents' potential route for heavy metals removal-A review. Environ. Sci. Pollut. Res. 2020, 27, 24342-24356. [CrossRef] [PubMed]

24. Ahmad, T.; Danish, M. Prospects of banana waste utilization in wastewater treatment: A review. J. Environ. Manag. 2018, 206, 330-348. [CrossRef]

25. Kulshreshtha, S. Removal of pollutants using spent mushrooms substrates. Environ. Chem. Lett. 2019, 17, 833-847. [CrossRef]

26. Lau, K.L.; Tsang, Y.Y.; Chiu, S.W. Use of spent mushroom compost to bioremediate PAH-contaminated samples. Chemosphere 2003, 52, 1539-1546. [CrossRef]

27. Nitschke, J.; Altenbach, H.-J.; Malolepszy, T.; Mölleken, H. A new method for the quantification of chitin and chitosan in edible mushrooms. Carbohydr. Res. 2011, 346, 1307-1310. [CrossRef] [PubMed]

28. Rasoulzadeh, H.; Dehghani, M.H.; Mohammadi, A.S.; Karri, R.R.; Nabizadeh, R.; Nazmara, S.; Kim, K.-H.; Sahu, J.N. Parametric modelling of $\mathrm{Pb}$ (II) adsorption onto chitosan-coated $\mathrm{Fe}_{3} \mathrm{O}_{4}$ particles through $\mathrm{RSM}$ and DE hybrid evolutionary optimization framework. J. Mol. Li. 2019, 297, 111893. [CrossRef]

29. Ertugay, N.; Bayhan, Y.K. Biosorption of Cr (VI) from aqueous solutions by biomass of Agaricus bisporus. J. Hazard. Mater. 2008, 154, 432-439. [CrossRef] [PubMed]

30. Ertugay, N.; Bayhan, Y.K. The removal of copper (II) ion by using mushroom biomass (Agaricus bisporus) and kinetic modelling. Desalination 2010, 255, 137-142. [CrossRef]

31. Soldi, E.; Casey, C.; Murphy, B.R.; Hodkinson, T.R. Fungal endophytes for grass-based bioremediation: An endophytic consortium isolated from Agrostis stolonifera stimulates the growth of Festuca arundinacea in lead contaminated soil. J. Fungi. 2020, 6, 254. [CrossRef]

32. Menk, J.J.; Nascimento, A.I.S.; Leite, F.G.; Oliveira, R.A.; Jozala, A.F.; Oliveira Junior, J.M.; Chaud, M.V.; Grotto, D. Biosorption of pharmaceutical products by mushroom stem waste. Chemosphere 2019, 237, 124515. [CrossRef]

33. Chen, S.H.; Cheow, Y.L.; Ng, S.L.; Ting, A.S.Y. Bioaccumulation and biosorption activities of indoor metal-tolerant Penicillium simplicissimum for removal of toxic metals. Int. J. Environ. Res. 2020, 14, 235-242. [CrossRef]

34. Amar, M.B.; Walha, K.; Salvadó, V. Evaluation of Olive Stones for Cd(II), $\mathrm{Cu}(\mathrm{II}), \mathrm{Pb}(\mathrm{II})$ and $\mathrm{Cr}(\mathrm{VI})$ Biosorption from aqueous solution: Equilibrium and kinetics. Int. J. Environ. Res. 2020, 14, 193-204. [CrossRef]

35. Sips, R. On the Structure of a catalyst surface. J. Chem. Phys. 1948, 16, 490-495. [CrossRef]

36. Foo, K.Y.; Hameed, B.H. Insights into the modeling of adsorption isotherm systems. Chem. Eng. J. 2010, 156, 2-10. [CrossRef]

37. Pedron, T.; Segura, F.R.; da Silva, F.F.; de Souza, A.L.; Maltez, H.F.; Batista, B.L. Essential and non-essential elements in Brazilian infant food and other rice-based products frequently consumed by children and celiac population. J. Food Compot. Anal. 2016, 49, 78-86. [CrossRef]

38. Liu, H.; Guo, S.; Jia, Z.; Han, Y.; He, Q.; Xu, H. Alleviating the toxicity of heavy metals by combined amendments in cultivated bag of Pleurotus cornucopiae. Environ. Sci. Pollut. R 2015, 22, 17182-17191. [CrossRef]

39. El-Ashtoukhy, E.-S.Z.; Amin, N.K.; Abdelwahab, O. Removal of lead (II) and copper (II) from aqueous solution using pomegranate peel as a new adsorbent. Desalination 2008, 223, 162-173. [CrossRef]

40. Amarasinghe, B.M.W.P.K.; Williams, R.A. Tea waste as a low cost adsorbent for the removal of $\mathrm{Cu}$ and $\mathrm{Pb}$ from wastewater. Chem. Eng. J. 2007, 132, 299-309. [CrossRef]

41. Li, X.; Zhang, D.; Sheng, F.; Qing, H. Adsorption characteristics of Copper (II), Zinc (II) and Mercury (II) by four kinds of immobilized fungi residues. Ecotox. Environ. Saf. 2018, 147, 357-366. [CrossRef]

42. Liu, S.H.; Zeng, G.M.; Niu, Q.Y.; Liu, Y.; Zhou, L.; Jiang, L.H.; Tan, X.F.; Xu, P.; Zhang, C.; Cheng, M. Bioremediation mechanisms of combined pollution of PAHs and heavy metals by bacteria and fungi: A mini review. Bioresour Technol. 2017, 224, 25-33. [CrossRef]

43. Dwivedi, A.D.; Dubey, S.P.; Gopal, K.; Sillanpää, M. Strengthening adsorptive amelioration: Isotherm modeling in liquid phase surface complexation of $\mathrm{Pb}$ (II) and Cd (II) ions. Desalination 2011, 267, 25-33. [CrossRef] 
44. Umpleby, R.J.; Baxter, S.C.; Chen, Y.; Shah, R.N.; Shimizu, K.D. Characterization of molecularly imprinted polymers with the Langmuir-Freundlich isotherm. Anal. Chem. 2001, 73, 4584-4591. [CrossRef]

45. García-Delgado, C.; Jiménez-Ayuso, N.; Frutos, I.; Gárate, A.; Eymar, E. Cadmium and lead bioavailability and their effects on polycyclic aromatic hydrocarbons biodegradation by spent mushroom substrate. Environ. Sci. Pollut. R 2013, 20, 8690-8699. [CrossRef]

46. Qiao, X.; Huang, W.; Bian, Y. Effective removal of cadmium ions from a simulated gastrointestinal fluid by Lentinus edodes. Int. J. Environ. Res. Public. Health 2014, 11, 12486-12498. [CrossRef] [PubMed] 